\title{
Measurement of sand grain distribution to gauge liquefaction risks at six key coastal west sumateran sites
}

\author{
Fuji Asema ${ }^{1 *}$ \\ ${ }^{1}$ Magister Program, Civil Engineering Dept., Faculty of Engineering, Andalas University, Padang
}

\begin{abstract}
It is well known that earthquake-induced liquefaction can cause remarkable damage to buildings. A recent disaster involving liquefaction in Palu damaged buildings and infrastructure and has become the focus of many researchers. Detailed study of liquefaction is necessary in order to have a good understanding and direct mitigation efforts for the future. In this study, the liquefaction potential of sands with various grain size distributions was analyzed. The research was experimental using a laboratory sieve shaker. The samples were taken from six areas near important facilities. From this, the relationship between grain distribution and liquefaction potential could be plotted and this information could become an important input for liquefaction mitigation efforts in sandy sediment areas.
\end{abstract}

\section{Introduction}

Liquefaction occurs when the pore water pressure increases due to an earthquake until the effective stress became zero. This decreases the interlocking between the grains was decreased and the strength of soil disappears. Water fills in the pores so that the characteristics of soil change from solid to liquid and loses bearing capacity. This results in damage to structures that can no longer be supported by the soil underneath them.

Liquefaction potential is a function of several factors [1]: a) The Initial Relative density, b) Initial Pressure, c) Mean Grain Size, d) Maximum Shear Stress, e) Over Consolidation Ratio, f) Pore water pressure. The grain size distribution of soil can be determined by means of sieve analysis and can be determine the characteristics of soil. Grain size distribution may be uniform, well-graded or gap-graded.

The liquefaction due to the $7.4 \mathrm{Mw}$ of earthquake in Palu on September 28, 2018 destroyed houses and roads. Petobo and Balaroa were at the center of damage. Relocation is the one solution for these towns.

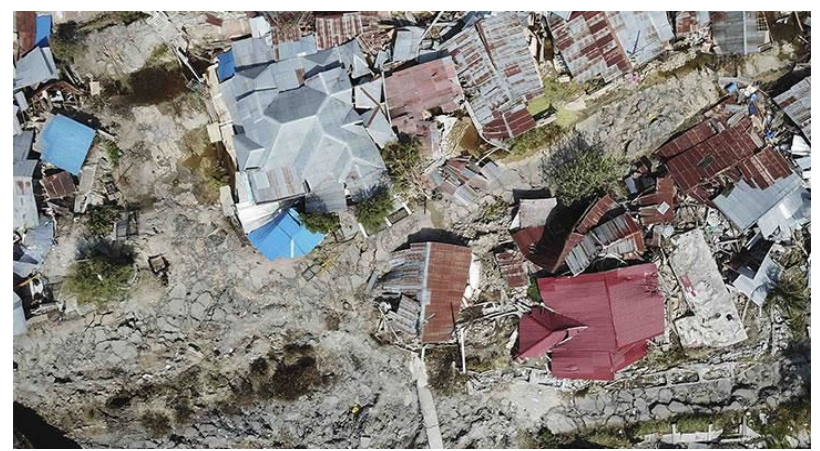

Fig. 1. Liquefaction in Petobo
An earthquake that caused liquefaction occurred in the city of Padang on September 30, 2009. The occurrence of liquefaction was marked by the presence of sand boils at several points in the city of Padang [2].
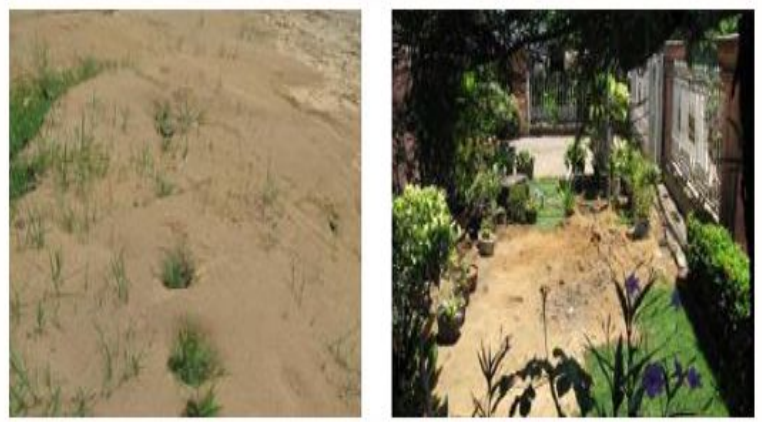

Fig. 2. Sand boils on the ground level

Seeing the impact caused by liquefaction, researchers in the past have devised several methods to analyze the liquefaction potential. Analysis of liquefaction potential using field and laboratory test data.

Field analysis of liquefaction potential includes a Cone Penetration Test (CPT) [3], Standard Penetration Test (SPT) [4], and Triaxial test [5]. Analysis of liquefaction has involved measuring flow velocities of seepage [6]. The effects of fines content, grain size distribution, and shape characteristics of sands have also been investigated by [7].

When measured for the same number of cycles, a soil with higher relative density has a higher cyclic stress ratio which indicates the liquefaction resistance. That means relative density is correlated with liquefaction resistance [8]. This study investigates the correlation between grain size distribution and liquefaction potential.

\footnotetext{
$\bar{*}$ Corresponding author: fujiasema11@gmail.com
} 


\section{Sampling Location}

The samples were taken at 6 points in different areas. Two points in Pariaman city, two points in Padang city, and two points in Bungus area. They are near the important public facilities below:

1. Terapung Mosque, Pariaman

2. West Sumatera Pelayaran Polytechnic, Pariaman

3. Rusunawa, Padang

4. State University of Padang, Padang

5. Teluk Bayur Port

6. PT. Pertamina, Bungus

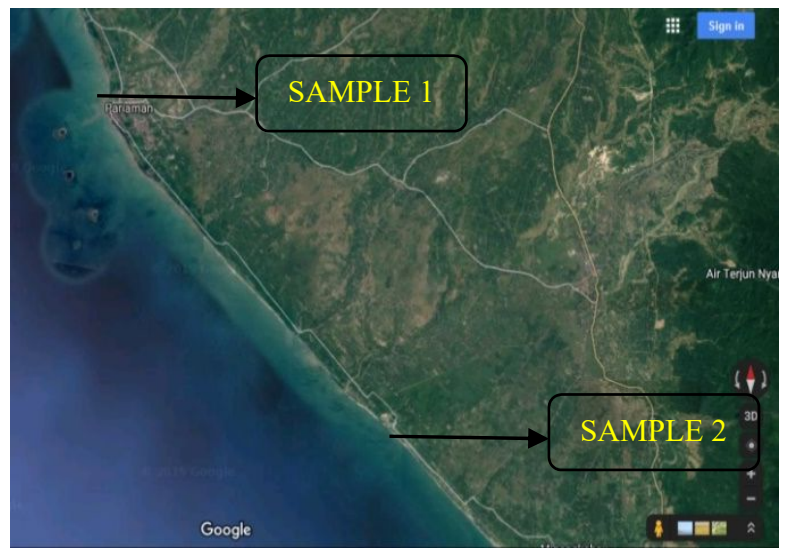

(a)

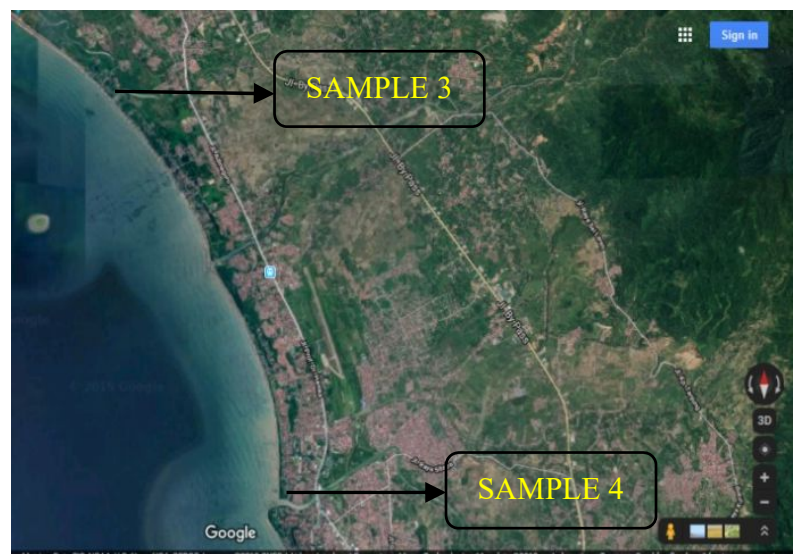

(b)

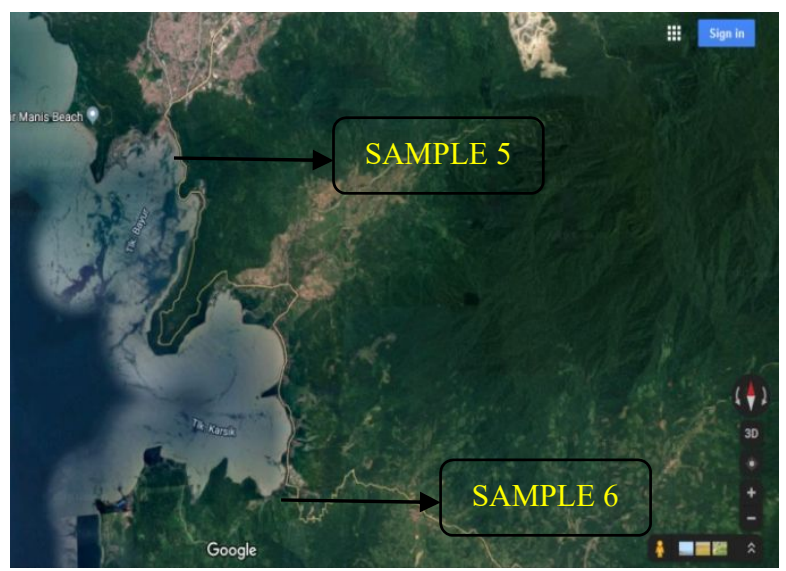

(c)

Fig. 3. Sampling location in a) Pariaman area, b) Padang area, c) Bungus area

\section{Methodology}

The procedures of this study are following:

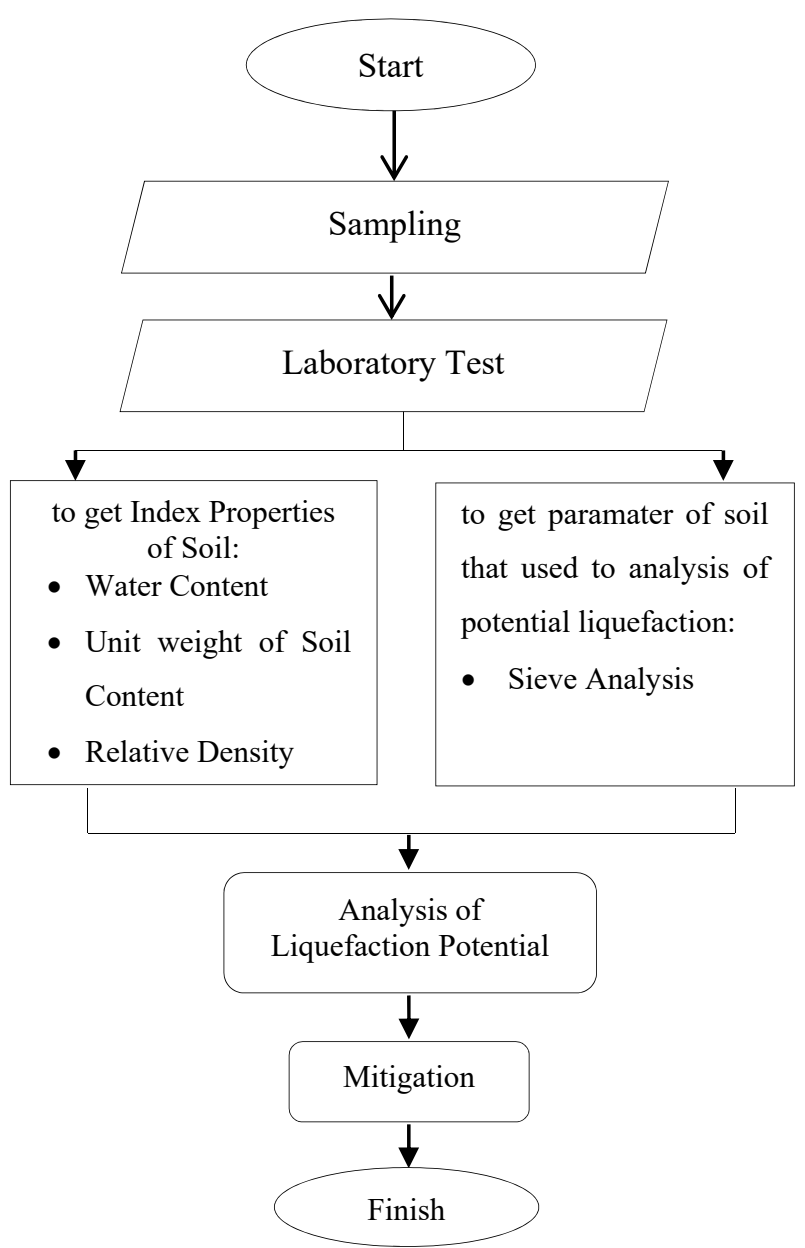

Fig. 4. Procedures of this study

The soil parameters used in this study are grain distribution and relative density of soil. Grain distribution is needed to describe the relationship between average grain size and liquefaction potential. Relative density (Dr) is the soil density in dry conditions.

\section{Result and Discussion}

Laboratory results are as below :

\subsection{Water Content}

Laboratory results are :

Table 1. Result of Water Content

\begin{tabular}{cc} 
Sample & W $(\%)$ \\
\hline 1 & 8.82 \\
\hline 2 & 5.45 \\
\hline 3 & 8.87 \\
\hline 4 & 9.41 \\
\hline 5 & 7.87 \\
\hline 6 & 5.48
\end{tabular}




\subsection{Unit Weight of Soil Content}

The formulae used for unit weight of soil content are :

When :

$$
\gamma=\frac{W}{V}
$$

$\gamma \quad=$ Unit weight of soil content

$\mathrm{W}=$ (Unit weight of soil + cylinder $)-$ Weight of cylinder

$\mathrm{V} \quad=$ Volume of cylinder

The results are :

Table 2. Results Unit Weight of

\begin{tabular}{cc}
\multicolumn{2}{c}{ Soil Content } \\
Sample & $\begin{array}{c}\gamma \\
\left(\mathrm{gr} / \mathrm{cm}^{3}\right)\end{array}$ \\
\hline 1 & 1.778 \\
\hline 2 & 1.611 \\
\hline 3 & 1.473 \\
\hline 4 & 1.644 \\
\hline 5 & 1.490 \\
\hline 6 & 1.622
\end{tabular}

\subsection{Relative Density}

Dry unit weight, dry unit weight maximum and dry unit weight minimum can be calculated as below :

Table 3. Results of dry unit weight, dry unit weight maximum and dry unit weight minimum

\begin{tabular}{cccc} 
Sample & $\begin{array}{c}\gamma d \\
\left(\mathrm{gr} / \mathrm{cm}^{3}\right)\end{array}$ & $\begin{array}{c}\gamma d \max \\
\left(\mathrm{gr} / \mathrm{cm}^{3}\right)\end{array}$ & $\begin{array}{c}\gamma d \text { min } \\
\left(\mathrm{gr} / \mathrm{cm}^{3}\right)\end{array}$ \\
\hline 1 & 1.634 & 1.277 & 1.182 \\
\hline 2 & 1.528 & 1.252 & 1.087 \\
\hline 3 & 1.353 & 1.098 & 0.893 \\
\hline 4 & 1.503 & 1.290 & 1.064 \\
\hline 5 & 1.381 & 1.239 & 1.079 \\
\hline 6 & 1.538 & 1.419 & 1.131
\end{tabular}

Unit weight of soil content and water content then combined. Then relative density can be obtained by:

Table 4. Results of relative density

\begin{tabular}{cc} 
Sample & Dr \\
\hline 1 & 3.172 \\
\hline 2 & 2.196 \\
\hline 3 & 1.819 \\
\hline 4 & 1.668 \\
\hline 5 & 1.697 \\
\hline 6 & 1.303
\end{tabular}

Base on relative density and unit weight of soil content, then classified type of soil density, [9].

Table 5. Type of soil density

\begin{tabular}{lll} 
Type & Dr & $\gamma\left(\mathrm{t} / \mathrm{m}^{3}\right)$ \\
\hline Very loose & $0-15$ & $1.1-1.6$ \\
\hline Loose & $15-50$ & $1.4-1.8$ \\
\hline Medium & $50-70$ & $1.7-2.0$ \\
\hline Dense & $70-85$ & $1.7-2.2$ \\
\hline Very dense & $85-100$ & $2.0-2.3$
\end{tabular}

The relative density and unit weight of soil content allows classification about the type of soil density. In general, the soil densities were very loose.

\subsection{Grain Size Distributions}

The results of sieve shaker tests for six sample are as follow :

Table 6. Results for Coefficient of Uniformity

\begin{tabular}{cc} 
Sample & $\mathrm{Cu}$ \\
\hline 1 & 2.29 \\
\hline 2 & 1.56 \\
\hline 3 & 1.91 \\
\hline 4 & 1.72 \\
\hline 5 & 2.55 \\
\hline 6 & 1.38
\end{tabular}

And could be plotted as below.

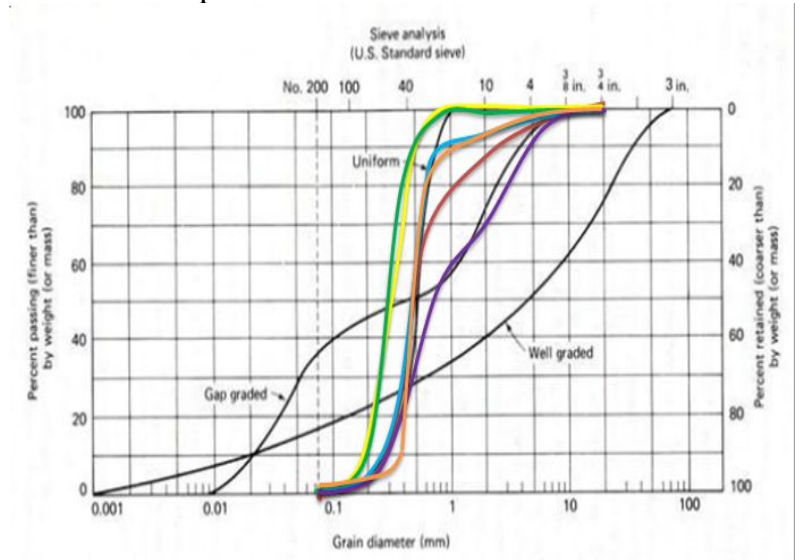

Fig. 5. Sieve Analysis

These results show that the characteristics of the soil are relatively uniform.

\subsection{Liquefaction Potential Based on Grain Size}

The soil in the laboratory test were compared with a range of liquefable soil from Tsuchida in [10], liquefaction criteria based on grain size distributions are as shown in fiqures below.

Sample 1 (Terapung Mosque, Pariaman)

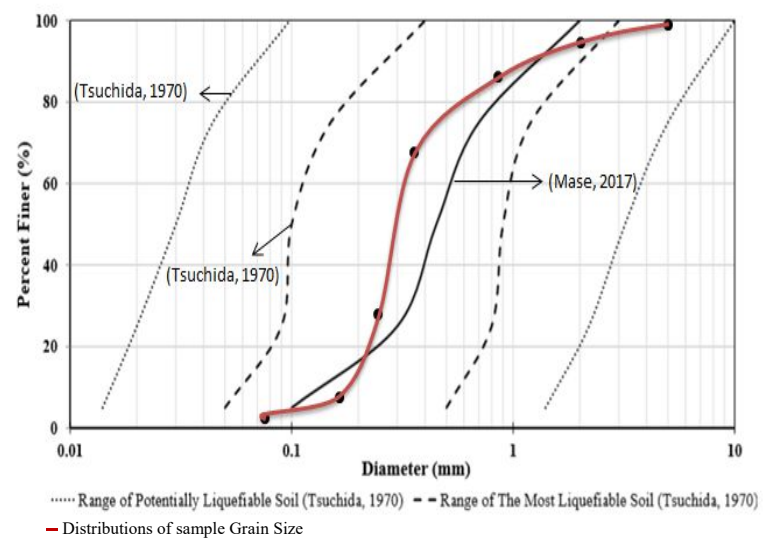

Fig. 6. Liquefaction Potential for Sample 1 
Sample 2 (West Sumatera Pelayaran Polytechnic, Pariaman)

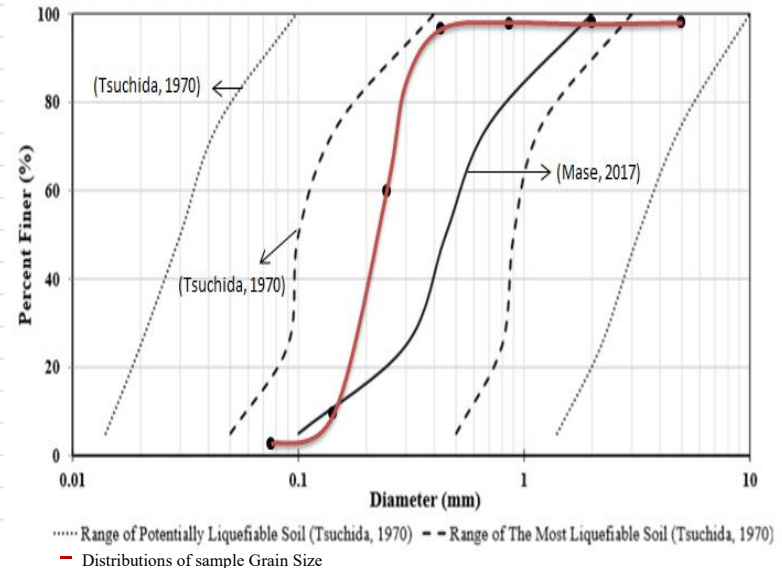

Fig. 7. Liquefaction Potential for Sample 2

Sample 3 (Rusunawa, Padang)

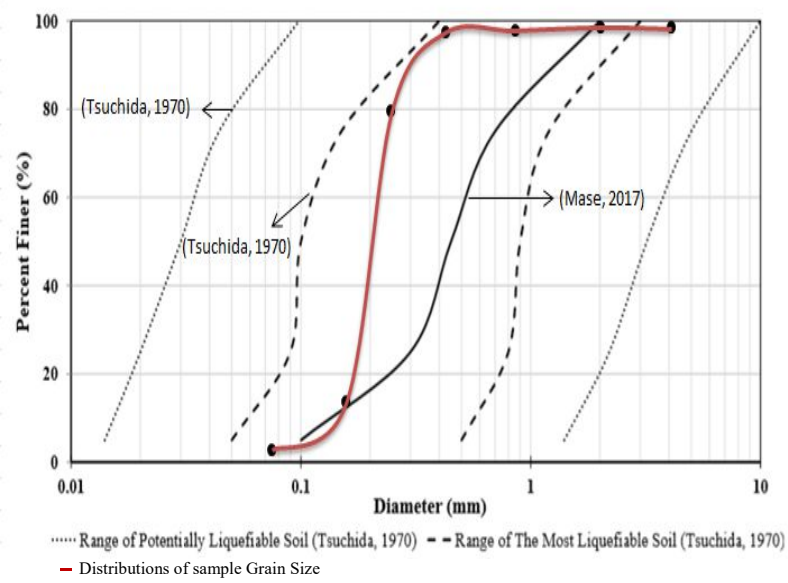

Fig. 8. Liquefaction Potential for Sample 3

Sample 4 (State University of Padang, Padang)

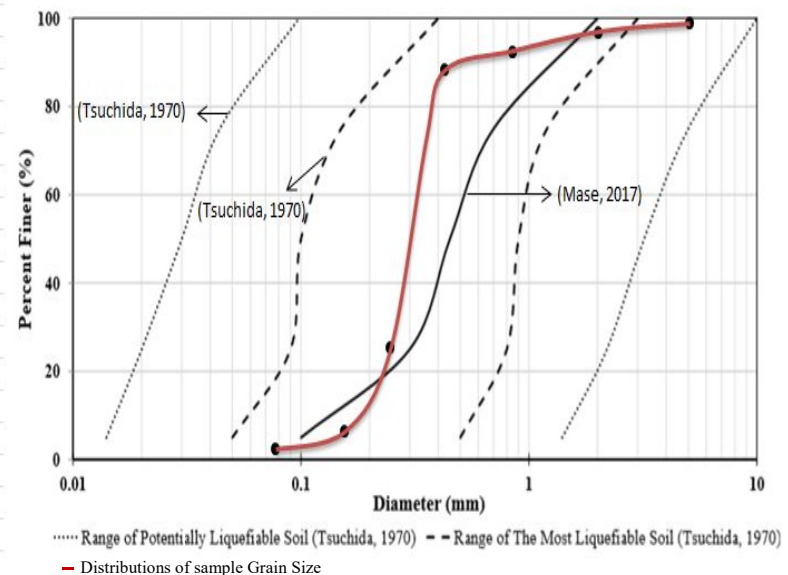

Fig. 9. Liquefaction Potential for Sample 4
Sample 5 (Teluk Bayur Port)

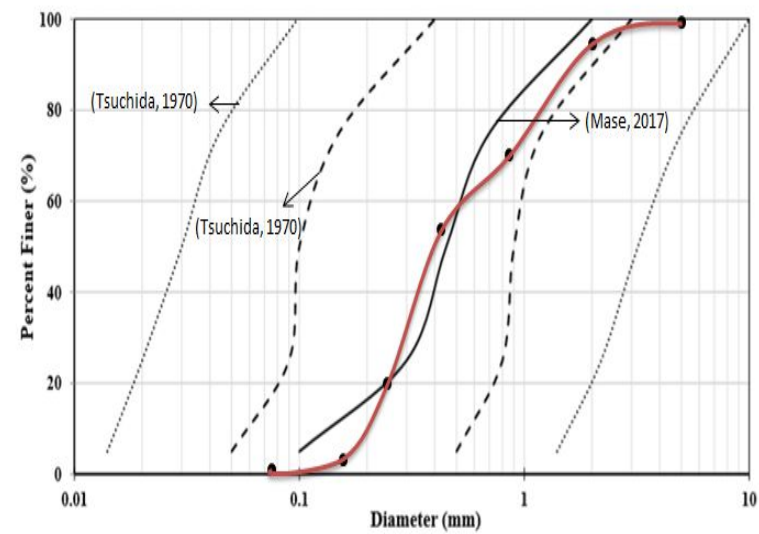

...... Range of Potentially Liquefiable Soil (Tsuchida, 1970) - - Range of The Most Liquefiable Soil (Tsuchida, 1970) - Distributions of sample Grain Size

Fig. 10. Liquefaction Potential for Sample 5

Sample 6 (PT. Pertamina, Bungus)

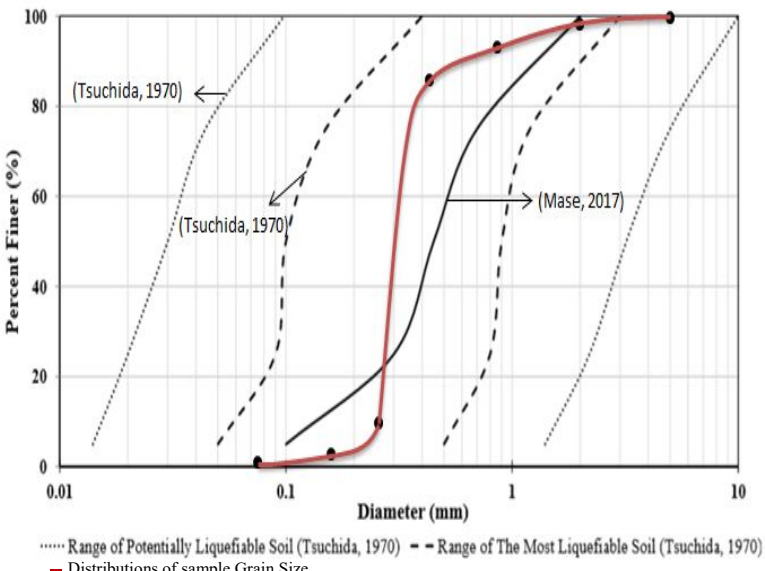

Fig. 11. Liquefaction Potential for Sample 6

It would appear that all samples fall within the range of potentially liquefable soil. That means all tested areas are at potential liquefaction risk.

\section{Conclusion}

Values of relative density and unit weight of soil content indicated soil density typical of very loose soils at all sites. These very loose soils have large inter-pore cavities reducing interlocking. These coastal areas also have high groundwater levels and if an earthquake occurs, the groundwater level will increase filling the pores with water resulting in an increased risk of liquefaction. This can cause the bearing capacity of soil to be reduced. The grain size distributions of the soils were uniform which also reduces the interlocking between grain and can also contribute to liquefaction. All of the six sites surveyed carry a liquefaction risk and consideration of mitigation would be advisable. Future analysis will include a shaking table test. 


\section{References}

1. B. M. Das, Fundamental of Soil Dynamics, New York: Elsevier Pub., 365 (1983)

2. A. Hakam, E. Suhelmidawati, Proc. Eng., 54, $140-$ 146 (2013)

3. D. Sarah, E. Subowo, Proc. E. and P. S., 6, $383-$ 389 (2013)

4. J. T. Hatmoko, H. Suryadharma, Proc. Eng. 125, $311-316$ (2015)

5. Y. Yilmas, M. M., V. Ozaydin, K. Kayabali, Proc. Eng. Geo., 100, 91-100 (2008)
6. T. S. Ueng, Z. F. Wang, M.C Chu, L.Ge, S. D. and E. Eng. 100, 249-256 (2017)

7. M. M. Monkul, E. Etminan, A. Senol, S. D. and E. Eng. 101, 12-26 (2017)

8. A. Hakam, Jr. Eng. Tech. and Sci., 48, 334-344 (2016)

9. B. M. Das, Prinsiples of Foundation Engineering, New York : Global Engg. Pub. (2014)

10. L. Z. Mase, Int. Jr. of Tech., 4, 747-760 ( 2017) 